\title{
Erratum to: The functional biology and trophic role of krill (Thysanoessa raschii) in a Greenlandic fjord
}

Mette Dalgaard Agersted • Torkel Gissel Nielsen •

Peter Munk • Bent Vismann • Kristine Engel Arendt

Published online: 3 July 2014

(C) Springer-Verlag Berlin Heidelberg 2014

Erratum to: Mar Biol (2011) 158:1387-1402

DOI 10.1007/s00227-011-1657-z

Unfortunately, in the original version of article, Fig. 2 was incorrectly published. The corrected figure is given below:

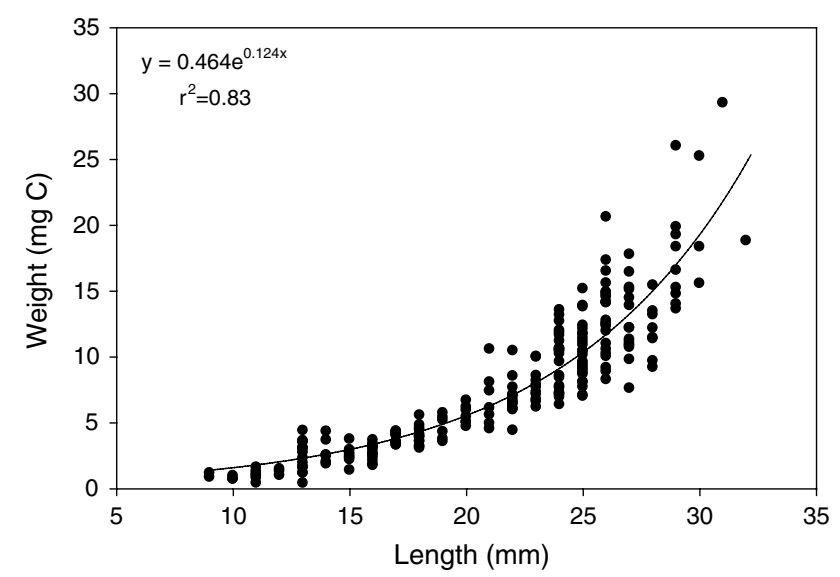

Fig. 2 Thysanoessa raschii. Estimated length-weight relation $(n=240)$

The online version of the original article can be found under doi:10.1007/s00227-011-1657-z.

M. D. Agersted · T. G. Nielsen $(\bowtie) \cdot$ P. Munk

DTU Aqua, National Institute of Aquatic Resources,

Section for Ocean Ecology and Climate, Jægersborg Alle 1, 2920 Charlottenlund, Denmark

e-mail: tgin@aqua.dtu.dk

M. D. Agersted · B. Vismann

Marine Biological Laboratory, Institute of Biology, University

of Copenhagen, Strandpromenaden 5, 3000 Helsingør, Denmark

K. E. Arendt

Greenland Climate Research Centre, c/o Greenland Institute of Natural Resources, PO Box 570, Kivioq 2, 3900 Nuuk,

Greenland 